\title{
BINDING OF OESTRADIOL TO RABBIT BLASTOCYSTS AND ITS POSSIBLE RÔLE IN IMPLANTATION
}

\author{
B. M. BHATT AND D. W. BULLOCK \\ Departments of Obstetrics and Gynecology and of Physiology, \\ Albany Medical College, Albany, New York 12208, U.S.A.
}

(Received 30th November 1973)

\begin{abstract}
Summary. Intraluminal injection of the anti-oestrogen, CI-628, into one uterine horn of rabbits on Day 5 of pregnancy inhibited implantation compared to the control horn. Exposure of 5-day blastocysts to $5 \times 10^{-6}$ M-CI-628 in vitro prevented their implantation after transfer to synchronized pseudopregnant recipients. Incubation of blastocysts with CI-628 followed by further incubation in inhibitor-free medium significantly restored the proportion of implantations. Binding of $\left[{ }^{3} \mathrm{H}\right]$ oestradiol to Day- 5 or Day- 6 blastocysts was reduced by CI-628 and sucrose density gradient fractionation of blastocyst cytosol, incubated with $\left[{ }^{3} \mathrm{H}\right]$ oestradiol, revealed binding of radioactivity to soluble protein which was displaced in the presence of the inhibitor. The results implicate oestradiol in the development or implantation of the rabbit blastocyst and are consistent with the hypothesis that this steroid may act as a local signal from the blastocyst to the uterus.
\end{abstract}

\section{INTRODUCTION}

From the evidence that exogenous progesterone will induce implantation after ovariectomy in the rabbit (Wu \& Allen, 1959), it has been generally accepted that oestrogen is not required for nidation in this species. Chambon (1949) suggested, however, that small amounts of oestrogen may be necessary. In rodents, the site of implantation can be visualized by means of dyes, such as Evans blue or pontamine blue, before attachment of the blastocyst (Psychoyos, 1961; Orsini, 1963). Such findings have led to the concept that the blastocyst might participate in the events leading to its own implantation, by signalling its presence to the uterus.

We have re-examined the rôle of oestradiol in implantation in the rabbit and have developed the idea that the postulated signalling mechanism from the blastocyst to the uterus may involve oestradiol bound to the blastocyst, possibly to an oestrogen receptor protein which the blastocyst might contain. This paper reports experiments designed to test this hypothesis by examining whether inhibition of receptor binding sites would interfere with implantation and by attempting to identify oestrogen receptor protein in the blastocyst. 


\section{MATERIALS AND METHODS}

An inhibitor of oestradiol binding to its receptor protein, CI-628 (1-[2-(p$[\alpha$-(p-methoxyphenyl)- $\beta$-nitrostyryl $]$ phenoxy)ethyl $]$ pyrrolidine, monocitrateCallantine \& co-authors, 1966), was used as an oestrogen antagonist both in vivo and in vitro. Adult, female, New Zealand white rabbits were injected on Day 5 of pregnancy with $200 \mu \mathrm{g}$ CI-628 in saline intraluminally in one uterine horn, with a similar volume of saline $(0.2 \mathrm{ml})$ injected into the lumen of the opposite horn to act as a control. At this time, the number of corpora lutea on each ovary was recorded. On Day 12 of pregnancy, the uteri were exposed under pentobarbital anaesthesia and the number of implantation sites was counted. The viability of the embryos was determined by observing their heart beat.

To distinguish between an action of the inhibitor on the blastocyst and on the uterus, 5-day blastocysts were incubated in $1.0 \mathrm{ml}$ TC medium 199 for $1 \mathrm{hr}$ at $37^{\circ} \mathrm{G}$ with or without CI-628 $\left(5 \times 10^{-6} \mathrm{M}\right)$. The treated and untreated blastocysts were transferred to opposite uterine horns of synchronized pseudopregnant recipients and the numbers of implantations and viable embryos were recorded 7 days later.

In an attempt to assess possible toxic effects of the inhibitor on the blastocyst, 5-day blastocysts were incubated with or without CI-628 under the above conditions for $1 \mathrm{hr}$ and were then placed in fresh medium without CI-628 and were incubated for a further hour. At the end of the second hour of incubation, egg transfer was carried out as described above.

Binding of oestradiol was investigated by incubating 5- and 6-day blastocysts in $0.01 \mathrm{M}$-tris buffer, $\mathrm{pH} 7 \cdot 4$, containing $3 \times 10^{-8} \mathrm{M}-\left[6,7-{ }^{3} \mathrm{H}\right]$ oestradiol (sp. act. $50 \mathrm{Ci} / \mathrm{mmol}$ ), for $1 \mathrm{hr}$ at $4^{\circ} \mathrm{C}$ with or without CI-628 $\left(10^{-5} \mathrm{M}\right)$. After incubation, the blastocysts were washed three times with cold buffer and transferred to counting vials containing $1.0 \mathrm{ml}$ tissue solubilizer (NCS, AmershamSearle). The vials were maintained at $50^{\circ} \mathrm{C}$ for $2 \frac{1}{2} \mathrm{hr}$ after which $10 \mathrm{ml}$ of a mixture comprising 5.0 g Omnifluor (New England Nuclear), $500 \mathrm{ml}$ Triton $\mathrm{X}-100$ and 1 litre toluene were added and the radioactivity was counted in a liquid scintillation counter. Quenching was similar for all vials and no correction for counting efficiency was made.

For the study of oestrogen receptor protein, a cytosol was prepared from 200 5-day and twenty-six 6-day blastocysts by centrifugation (100,000 $\mathrm{g}$ for $1 \frac{1}{2} \mathrm{hr}$ ) of a supernatant from an homogenate in $0.01 \mathrm{M}$-tris/0.0015 M-EDTA buffer, $\mathrm{pH} 7 \cdot 4$. The cytosol was incubated with $2.5 \times 10^{-9} \mathrm{M}-\left[2,4,6,7-{ }^{3} \mathrm{H}\right]-$ oestradiol (sp. act. $105 \mathrm{Gi} / \mathrm{mmol}$ ) for $1 \mathrm{hr}$ at $4^{\circ} \mathrm{C}$ with or without GI-628 $\left(0.8 \times 10^{-6} \mathrm{M}\right)$. Portions of the incubation mixtures $(0.2 \mathrm{ml})$ were layered on 5 to $20 \%$ sucrose density gradients and centrifuged at $240,000 \mathrm{~g}$ for $15 \mathrm{hr}$. The gradients were divided into $0 \cdot 1-\mathrm{ml}$ fractions and the radioactivity in each fraction was counted.

\section{RESULTS}

Table 1 shows the effect on implantation of intrauterine injection of CI-628. The inhibitor almost completely prevented implantation and there were no 
Table 1. Effect of intrauterine injection of CI-628 on the implantation of rabbit blastocysts

\begin{tabular}{l|c|c|c|c}
\hline & No. of rabbits & No. of $C L$ & $\begin{array}{c}\text { No. of } \\
\text { implantations }\end{array}$ & $\begin{array}{c}\text { No. of viable } \\
\text { embryos }\end{array}$ \\
\hline $\begin{array}{c}\text { Control horn } \\
\text { Treated horn } \\
(200 \mu \mathrm{g} \text { CI-628) }\end{array}$ & 4 & 18 & 15 & $8^{*}$ \\
\hline
\end{tabular}

* No. of rabbits $=3$.

Table 2. Implantation after incubation of rabbit blastocysts with CI-628

\begin{tabular}{l|c|c|c|c}
\hline & $\begin{array}{c}\text { No. of } \\
\text { rabbits }\end{array}$ & $\begin{array}{c}\text { No. of } \\
\text { blastocysts } \\
\text { transferred }\end{array}$ & $\begin{array}{c}\text { No. of } \\
\text { blastocysts } \\
\text { implanted }\end{array}$ & $\begin{array}{c}\text { No. of } \\
\text { viable embryos }\end{array}$ \\
\hline Control & 5 & 24 & $20(83)^{*}$ & $11(55)$ \\
Gr-628 $\left(5 \times 10^{-6} \mathrm{M}\right)$ & 5 & 24 & $3(13)$ & 0 \\
\hline
\end{tabular}

* Percentages in parentheses.

Table 3. Implantation of rabbit blastocysts after incubation with CI-628 and subsequent 'washing'

\begin{tabular}{l|c|c|c|c}
\hline & $\begin{array}{c}\text { No. of } \\
\text { rabbits }\end{array}$ & $\begin{array}{c}\text { No. of } \\
\text { blastocysts } \\
\text { transferred }\end{array}$ & $\begin{array}{c}\text { No. of } \\
\text { blastocysts } \\
\text { implanted }\end{array}$ & $\begin{array}{c}\text { No. of } \\
\text { viable embryos }\end{array}$ \\
\hline Control & 5 & 19 & $14(74) *$ & $6(43)$ \\
CI-628 $\left(5 \times 10^{-6} \mathrm{M}\right)$ & 5 & 21 & $9(43)$ & $2(22)$ \\
\hline
\end{tabular}

* Percentages in parentheses.

Table 4. Inhibition of $\left[{ }^{3} \mathrm{H}\right]$ oestradiol binding to rabbit blastocysts by $\mathrm{CI}-628$

\begin{tabular}{c|c|c}
\hline & $\begin{array}{c}\text { Day } 5(\mathrm{ct} / \mathrm{min} / \\
\text { blastocyst })\end{array}$ & $\begin{array}{c}\text { Day } 6(\mathrm{ct} / \mathrm{min} / \\
\text { blastocyst })\end{array}$ \\
\hline $\begin{array}{c}\left.{ }^{3} \mathrm{H}\right] \text { oestradiol }\left(3 \times 10^{-8} \mathrm{M}\right) \\
\begin{array}{c}{\left[{ }^{3} \mathrm{H}\right] \text { oestradiol }\left(3 \times 10^{-8} \mathrm{M}\right)} \\
\text { +CI-628 }\left(10^{-5} \mathrm{M}\right)\end{array}\end{array}$ & 237 & 12538 \\
\begin{tabular}{c} 
Inhibition $(\%)$ \\
\hline
\end{tabular} & 54 & 9305 \\
\hline
\end{tabular}




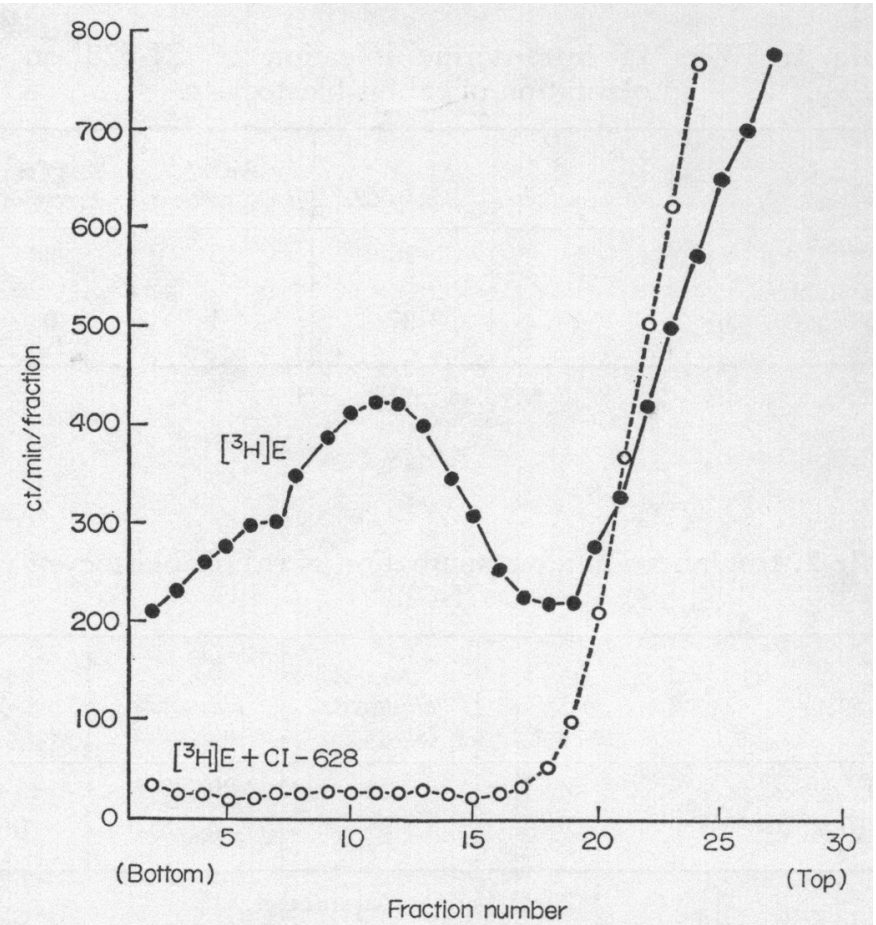

TEXT-FIG. 1. Inhibition by CI-628 of $\left[{ }^{3} \mathrm{H}\right]$ oestradiol $\left(\left[{ }^{3} \mathrm{H}\right] \mathrm{E}\right)$ binding to proteins of rabbit uterine cytosol separated by sucrose density gradient centrifugation.

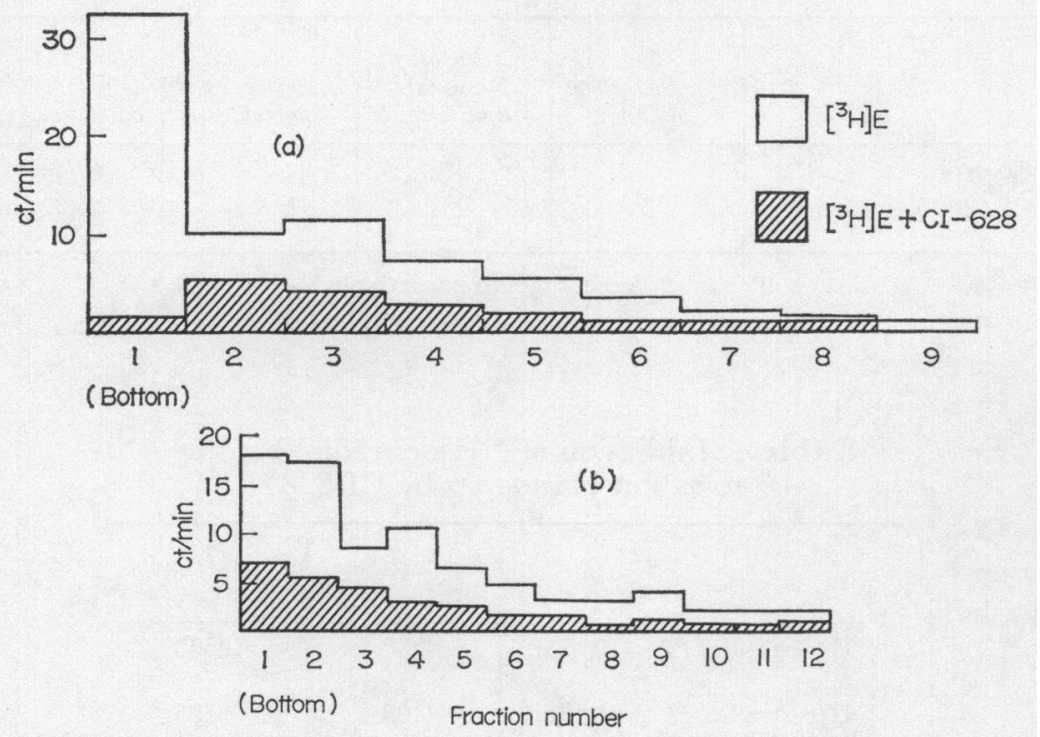

TExT-FIG. 2. Sucrose density gradient fractionation of (a) 5-day and (b) 6-day rabbit blastocyst cytosol incubated with $\left[{ }^{3} \mathrm{H}\right]$ oestradiol $\left(\left[{ }^{3} \mathrm{H}\right] \mathrm{E}\right)$ alone (open columns) or with GI-628 (shaded columns). 
viable embryos. Degenerate blastocysts were recovered from the treated horn, proving that a potential pregnancy had been present at the time of injection.

When blastocysts were transferred after exposure to CI- 628 in vitro, only $13 \%$ achieved implantation compared to $83 \%$ of the controls. None produced viable embryos compared to $55 \%$ viability in the controls (Table 2). The results of the 'washing' experiment (Table 3) show that these effects were not due to toxicity of the inhibitor. Although the proportion of treated blastocysts implanting after exposure to CI-628 followed by further incubation in fresh medium was less than in the controls, the rate of implantation was significantly increased $\left(\chi^{2}=3.84, P=0.05\right)$ compared to the previous experiment (Table 2).

Incubation in the presence of CI- 628 reduced the binding of $\left[{ }^{3} \mathrm{H}\right]$ oestradiol by $54 \%$ in the 5 -day and by $26 \%$ in the 6 -day blastocysts (Table 4 ).

To verify our ability to use CI-628 as an index of oestradiol binding to its receptor, we examined the effect of CI-628 on oestradiol-binding in a tissue where receptor was known to be present. Text-figure 1 shows the results of an experiment in which rabbit uterine cytosol was incubated with $\left[{ }^{3} \mathrm{H}\right]$ oestradiol in the presence or absence of CI-628 and fractionated on a sucrose density gradient. A large peak of $\left[{ }^{3} \mathrm{H}\right]$ oestradiol-binding, which was abolished in the presence of CI-628, indicated the location of the oestrogen receptor protein.

Applying this technique to the blastocyst, we obtained the results shown in Text-fig. 2. In 5-day (Text-fig. 2a) and 6-day (Text-fig. 2b) blastocysts, there was an accumulation of $\left[{ }^{3} \mathrm{H}\right]$ oestradiol bound to soluble protein at the bottom of the gradient and a displacement of this binding in the presence of CI-628.

\section{DISGUSSION}

In the original report describing the biological properties of CI-628, then known as CN-55,945-27, Callantine et al. (1966) reported a reduced decidual response in the traumatized rat uterus. The effect of intraluminal GI-628 on implantation might thus be attributed to an action on the uterine epithelium. The failure of implantation following exposure to CI-628 in vitro, however, suggests a direct action of the drug on the blastocyst. It is unlikely that the small amount of CI-628 bound to the blastocyst after incubation in a $5 \times 10^{-6} \mathrm{M}$ solution could render the whole length of the uterine horn unable to support implantation.

That the effect on the blastocyst was not one of general toxicity is shown by restoration of implantation after the drug was washed out. Callantine $e t$ al. (1966) also reported that oestrone could provoke implantation of blastocysts delayed by progesterone in rats treated with GI-628, indicating that the blastocysts were not damaged by the drug.

The reduction of oestradiol binding to 5- or 6-day blastocysts by CI-628 is consistent with the view that the effect of the inhibitor on implantation is due to its anti-oestrogenic properties exerted, in this case, directly on the blastocyst. Our data do not prove the existence of oestrogen receptor protein in the blastocyst but offer suggestive evidence for the presence of soluble proteins capable of specifically binding oestradiol. Inhibition of implantation by CI-628 can thus be presumed to be caused by interference with the action of oestrogen 
on the blastocyst. It therefore appears that oestrogen may after all be involved in implantation in the rabbit, as Chambon (1949) has suggested.

The concept that the blastocyst participates in the events leading to its own implantation is not a new one, and the possibility of an enzymatic or hormonal mechanism was advanced by Deanesly (1963). Our data suggest that oestradiol bound to the blastocyst may act as a local signal to the uterus. In this context, recent reports of oestradiol synthesis by pig blastocysts (Perry, Heap \& Amoroso, $1973)$ and the presence of $3 \beta$-hydroxysteroid dehydrogenase in rat blastocysts (Dickmann \& Dey, 1973) are of considerable interest.

\section{ACKNOWLEDGMENTS}

We thank Dr H. I. Jacobson for advice about receptor analysis and Mr Karl Ebert for his excellent technical assistance. The CI-628 was a gift from Dr J. Reel, Parke-Davis, Ann Arbor, Michigan. The work was supported by a grant from the Ford Foundation.

\section{REFERENCES}

Gallantine, M. R., Humphrey, R. R., Lee, S. L., Windsor, B. L., Schottin, N. H. \& O'Brien, O. P. (1966) Action of an estrogen antagonist on reproductive mechanisms in the rat. Endocrinology, 79, 153.

Chambon, Y. (1949) Besoins endocriniens qualitatifs et quantitatifs de l'ovoimplantation chez la lapine. C. r. Séanc. Soc. Biol. 143, 1172.

Deanesly, R. (1963) The corpus luteum hormone during and after ovo-implantation: an experimental study of its mode of action in the guinea pig. In Delayed Implantation, p. 254. Ed. A. C. Enders. Charles C. Thomas, Springfield, Ill.

Dickmann, Z. \& DeY, S. K. (1973) Two theories: the preimplantation embryo is a source of steroid hormones controlling (1) morula-blastocyst transformation, and (2) implantation. $\mathcal{J}$. Reprod. Fert. 35, 615.

Orsini, M. W. (1963) Morphological evidence on the intrauterine career of the ovum. In Delayed Implantation, p. 155. Ed. A. C. Enders. Charles C. Thomas, Springfield, Ill.

Perry, J. S., Heap, R. B. \& Amoroso, E. C. (1973) Steroid hormone production by pig blastocyst. Nature, Lond. 245, 45.

Psychoyos, A. (1961) Permeabilité capillaire et decidualization utérine. C. $r$. hebd. Séanc. Acad. Sci., Paris, 252, 1515.

WU, D. H. \& ALLEN, W. M. (1959) Maintenance of pregnancy in castrated rabbits by 17-alphahydroxy-progesterone caproate and by progesterone. Fert. Steril. 10, 439. 